\title{
The "ups" and "downs" of the upside-down: constructivist and self-determined learning in the flipped classroom during COVID-19
}

\section{Nina Hadžiahmetović ${ }^{1}$ \\ Department of Psychology, Faculty of Philosophy, University of Sarajevo}

The flipped classroom method (FCM) is based on individual online learning followed by student-teacher group interactions and has shown some advantages over traditional learning even in the pre-COVID-19 pandemic context. FCM is conducive to the constructivist learning approach, characterized by active knowledge construction rather than passive consumption of predetermined concepts. Both approaches are expected to facilitate the satisfaction of the basic psychological needs of autonomy, competence, and relatedness as proposed by self-determination theory (SDT). Given the outbreak of the COVID-19 pandemic, however, FCM has been imposed on many universities that lack the resources to take a constructivist approach and satisfy students' basic psychological needs. Considering the challenges of inverted teaching induced by the pandemic, this review paper aims to further address the following problems in an integrated theoretical framework: What are the pros and cons of the pandemic-constructed flipped classroom?; Is constructivist learning possible and to what extent during the pandemic?; How can a constructivist environment be created in the pandemic-constructed flipped classroom? Can the flipped classroom be used as a virtual mediator between the constructivist learning environment and students' basic psychological needs? More specifically, the purpose of this paper is to integrate constructivist learning within the flipped classroom method and to explore how constructivist learning may facilitate basic psychological needs through the characteristics of the flipped classroom. The paper proposes a conceptual framework of the constructivist environment associations with basic psychological needs through the perceived usefulness of technologymediated flipped classrooms. Specifically, it explores whether the communicative, instrumental, and pedagogical functions of the flipped classroom could help satisfy students' basic psychological needs. Challenges to the practical and empirical applications of the framework are discussed.

Keywords: constructivist learning, flipped classroom, basic needs, pandemic

1 ninochkaha@gmail.com 


\section{Introduction}

The outbreak of the COVID-19 infection at the end of 2019 and the subsequent pandemic declaration by the World Health Organization (WHO) on March 11, 2020 brought about substantial changes in almost every basic domain: public health, food systems, and the world of work (Chriscaden, 2020). On top of that, one greatly affected domain, requiring rapid adaptation to the new circumstances, is education (e.g. Di Pietro et al. 2020; Jain et al. 2020: Tadesse \& Muluye, 2020). The COVID-19 pandemic prompted a rapid transition of global learning systems to online teaching, disrupting everyday routines, with consequences for teachers' and students' psychological wellbeing. To cope with the transition more effectively, the flipped classroom method (FCM) has been increasingly applied as a teaching method. Out of 316 research articles on flipped learning published between 2012 and 2018, $85 \%$ were related to higher education context (Birgili et al., 2021), but flipped learning has yielded positive outcomes in secondary education as well (e.g. Cevikbas \& Kaiser, 2020; Sergis et al., 2017). One of the positive aspects of flipping the classroom is reflected in constructivist learning - a learner's ability to construct their own meaning of the learned material (McLeod, 2019), which might be an especially challenging task during the pandemic. On the other hand, motivation to construct meaning and engage actively in learning might be reduced due to the deprived basic psychological needs of autonomy, competence, and relatedness. In this theoretical synthesis, we are interested in describing and integrating these main concepts into a common framework, with the aim of investigating their dynamic processes in more detail.

In this context, the main goal of our paper is to explore in more depth whether constructivist learning is sustainable in the flipped classroom, and whether constructivist approach might further enable satisfying the basic psychological needs of autonomy, relatedness, and competence, in students. Regarding our main concerns, we first describe the flipped classroom method (FCM) and outline its (dis)advantages during the pandemic. We then reflect on the relationship of the constructivist learning approach with flipped learning in the time of the pandemic. We further reflect on selfdetermination, considering the integration of constructivism and flipped learning during the pandemic. Finally, we conclude by proposing a tentative conceptual framework of the outlined concepts with challenges to their practical and empirical application.

\section{The Pros and Cons of the Pandemic-Flipped Classroom}

The flipped classroom model (FCM) is a teaching method in which instructional material (e.g. slides, presentations, videos) is first learned prior 
to the class, followed by an in-class application of the knowledge acquired (van Alten et al., 2019). This teaching method is a form of blended learning, an umbrella term used to describe various combinations of face-to-face and online learning (Hrastinski, 2019). In a conventional flipped classroom, students learn their materials in advance through online learning platforms, followed by face-to-face discussion with teachers and peers during the class. Unlike traditional teacher-centred learning, where lectures are delivered in a one-size-fits-all fashion, with limited time for further questions (van Alten et al., 2019), the flipped classroom is a student-centred approach, encouraging independent learning at student's own pace and the in-class consolidation of the acquired knowledge (Sergis et al., 2018). Given the decentralization of the teacher's role, in-class lecturers play numerous additional roles, such as a theme expert, instructional designer, or media developer, giving students an opportunity to apply their knowledge and engage actively in the class (Shih \& Tsai, 2017).

To this point, the flipped classroom (or flipped learning, as it is usually called) has been used successfully in various subjects, especially the STEM (Science, Technology, Engineering, Mathematics) fields (Talley \& Scherer, 2013), to indicate environment-independent learning (Birgili et al., 2021). Compared with the traditional method, the flipped classroom has a positive effect on students' learning outcomes, satisfaction with the learning environment, and self-determination (Sergis et al., 2018). A content analysis of scientific papers published on flipped classrooms shows that flipped learning has a positive effect on academic achievement and enhanced students' cognitive (higher-order thinking), affective (motivation, engagement, enjoyment, interest), and soft (interaction, flexibility) skills (Birgili et al., 2021).

Importantly, in the pre-pandemic normal, blended learning was referred to as "the new normal" in education (Norberg et al., 2011), and about 35 to $63 \%$ of institutions of higher education offered some form of flipped learning (Dziuban et al., 2018). In unprecedented times, such as the pandemic, however, universities around the world transitioned to fully online learning, including online interactions instead of live face-to-face ones. As a result, the implementation of the flipped classroom significantly increased during lockdown (Collado-Vallero et al., 2021). The mitigating circumstances in this transition were found to be the prior use of a pre-pandemic conventional FCM and technology-supported small group discussions (e.g. Zoom breakout rooms) as a substitution for live group discussions in the classroom (BeasonAbmayr et al., 2021).

Research on pandemic-induced classroom flipping has provided mixed results. On the one hand, students were equally as effective in the fully flipped 
classroom as in the conventional flipped classroom (Hew et al., 2020), and they evaluated the fully flipped classroom more positively compared with online learning (Tang et al., 2020). Additionally, flipping was shown to be useful for improving a wide range of students' social skills (Latorre-Cosculluela et al., 2020). On the other hand, students were dissatisfied with their instructors' involvement with the course and knowledge of technology, as well as their own lack of technical skills (Torres Martín et al., 2021), and communication in online learning (Tang et al., 2020). In addition, students evaluated the establishment of learning goals, an effective learning environment, and effective communication as the most important characteristics of a learning experience (Dziuban et al., 2018).

Given the above, could flipped learning fulfil the requirements for excellence? According to van Alten et al. (2019), with proper designation, the flipped classroom could have promising results. Considering the high demands of online teaching during the pandemic, the (dis)advantages of the FCM in these challenging times must be explored. We attempted to synthesize the pros and cons of flipped learning in various sources, as outlined in Table 1. In addition, we tried to present them based on their reciprocity.

On the plus side, the transition to flipped learning proceeded seamlessly at universities that were familiar with the method and used online platforms (e.g. Moodle), without the need to rebuild organizational structures (Birgili et al., 2021). All the while, some universities were unprepared for online learning, in which case a new way of teaching was considered more to be crisis management than a new teaching method (Tang et al., 2020). Furthermore, defining the structure in flipped learning could be an advantage because a well-organized learning platform is expected to support internally motivated or self-determined learning (Shih \& Tsai, 2017). Student performance may also be reinforced by pre-class individual learning (Birgili et al., 2021). Still, to be able to provide high-quality materials for students, teachers must invest greater effort in creative solutions, which is time-consuming (Cevikbas \& Kaiser, 2020). In addition, teacher scaffolding may not fully satisfy 
Table 1

Pros and cons of flipped learning

\begin{tabular}{ll}
\hline Pros & Cons \\
\hline $\begin{array}{l}\text { Easy and low-cost transition } \\
\text { Structure definition } \\
\text { Pre-class preparation } \\
\text { (Birgili et al., 2021; }\end{array}$ & $\begin{array}{l}\text { Lack of preparedness } \\
\text { (Tang et al., 2020) }\end{array}$ \\
Shih \& Tsai, 2017) & Time-consuming materials preparation \\
Teacher scaffolding & (Cevikbas \& Kaiser, 2020) \\
(Cevikbas \& Kaiser, 2015) & \\
Independent learning & Teacher over-reliance \\
free time for reflection & (Tang et al., 2020) \\
and material consolidation & Great amount of cognitive load \\
active engagement & on self-determined learning \\
(Tang et al., 2020; van Alten et al., 2019) & Lack of syllabus adaptation for online teaching \\
Variety of presentation media & (van Alten et al., 2019) \\
(Hew et al., 2020) & Technology knowledge requirements \\
Increase in general motivation & Resistance to change \\
(Abeysekera \& Dawson, 2015) & (Birgili et al., 2021; Torres Martín et al., 2021) \\
\hline
\end{tabular}

student needs, as in some cases students prefer more teacher-centred traditional teaching. Furthermore, even though the FCM may fulfil all the pre-conditions for self-determined learning, students may still be reluctant to participate due to the higher demands on their learning capabilities (van Alten et al., 2019). The FCM offers numerous ways to present material (Hew et al., 2020), but this largely depends on the instructor's technical skills and, hence, the instructor's willingness to adapt to fast contextual changes. For example, nearly $70 \%$ of students agreed that teachers did not adapt the course syllabus to online teaching (Torres Martín et al., 2021).

It has been proposed that the FCM should promote the basic needs of autonomy, competence, and relatedness, which would increase the general motivation for learning (Abeysekera \& Dawson, 2015). It is worth mentioning, however, that the FCM is not always equally effective, as more complex contents (e.g. science and engineering majors) are better grasped through traditional learning (Tang et al., 2020).

One important advantage of the FCM is that it enables constructivist learning. This does not preclude the facilitation of constructivist learning by other teaching methods, but the pillars of the FCM (Flipped Learning Network, 2014) could be closely associated with a constructivist environment, which we further detail in the following section. 


\section{Flipped-Classroom Mediated Constructivist Learning in a Pandemic}

Constructivist theories comprise three broad branches of cognitive constructivism (by Piaget, 1954), social constructivism (by Vygotsky, 1978), and radical constructivism (by von Glaserfeld, 1974). Although all three schools are influential, in this section we focus on social constructivism since it provides the most appropriate background for self-regulated learning.

Social constructivism is an approach to teaching and learning that holds that learning is a collaborative process and that meaning is constructed from existing knowledge in social interactions (McLeod, 2019; Vygotsky, 1978). As such, constructivist learning is based on several principles (Kwan \& Wong, 2014; McLeod, 2019):

- All knowledge is constructed - the learner is not a passive absorber of pre-determined concepts;

- Learners are active participants in their learning - they use and accommodate their existing knowledge in social interactions;

- Knowledge is socially constructed - it develops as a result of social interaction; and

- Knowledge is personal - it comprises personally relevant experiences, attitudes, and values.

The constructivist learning approach is usually operationalized as a classroom environment and measured with the Constructivist Learning Environment Scale for pupils (CLES; Taylor et al. 1997) or its comparative student version (CLES-CS; Nix et al., 2005). On a conceptual level, both versions encompass five dimensions: Personal Relevance, Uncertainty (of Science), Critical Voice, Shared Control, and Student Negotiation. The constructivist learning environment scale was first developed to monitor the constructivist approach in math and science teaching (Taylor et al., 1997) but can be adapted to other fields (e.g. liberal studies; Kwan \& Wong, 2014). Given that higher education is to some extent science-based, this instrument is an appropriate choice for operationalizing the constructivist approach.

The five dimensions of the constructivist learning approach are as follows. Personal relevance consists of out-of-the-class experiences that may be used as a context for developing students' scientific skills. Uncertainty is related to the provisional status of scientific knowledge that is socially or culturally dependent. Critical voice assesses the extent to which it is acceptable to question teaching practices and the teacher's willingness to foster student criticism towards learning. Shared control is related to sharing control with teachers over learning and consists of several indicators: learning goals, learning activities management, and assessment criteria. Finally, Student negotiation assesses the opportunity for students to share their ideas with others, reflect on them, and attentively listen to others' ideas (Taylor et al., 1997). 
Personal relevance, critical voice, and shared control seem to have a stable, though differential, pattern of relationships with various outcomes in terms of student preference, learning motivation, critical thinking, and academic success. Personal relevance and critical voice were viewed more favourably by students than was shared control (Kwan \& Wong, 2014), which was the least preferred constructivist environment dimension in several studies (Ahmad et al., 2015; Cetin-Dindar, 2015; Kwan \& Wong, 2014). Personal relevance and critical voice were positively correlated and shared control negatively correlated with critical thinking (Kwan \& Wong, 2014). Personal relevance and critical voice were positive predictors of learning motivation in a highachieving student group, whereas in a low-achieving group, only shared control was a positive predictor of learning motivation (Ongowo et al., 2014). In terms of academic achievement, relatively successful students perceived their environment as more constructivist, were less anxious about assessment (Cetin-Dindar, 2015), and had a higher preference for a constructivist environment (Ongowo et al., 2014).

The Constructivist Learning Environment Scale is recommended for use in systemic reforms, as constructivism is a major referent of learning environment transformations (Taylor et al., 1997). One such transformation seems to be underway during the pandemic. Christian et al. (2020, p. 2) referred to George Kelly's (1955) theory of personal constructs, which proposes that people create constructs to predict continuously changing contexts. Literally translating classrooms to online teaching would probably be misguided (Christian et al., 2020), since many students' and teachers experiential and existential concerns would remain unresolved. According to Kelly, this state would cause anxiety, as an individual cannot anticipate events because existing constructs and interpretations are no longer useful (Fulgosi, 1997). Thus, it is important to integrate a constructivist approach in the long-term environmental changes caused by the COVID-19 pandemic. Additionally, the constructivist learning environment was positively correlated with the evaluated adequacy of educational facilities, which are necessary for implementing a constructivist approach in learning (Ahmad et al., 2015), especially following the transition to a fully flipped classroom.

Given this, how could the flipped classroom method be conducive to constructivist learning? The often-cited four pillars of flipped learning are known as FLIP: a flexible environment, learning culture, intentional content, and professional educator (The Flipped Learning Network, 2014). As described in Cevikbas and Kaiser (2020), a "flexible environment" is one that can be arranged to adapt to individual or group work; a "learning culture" encourages a student-centred approach according to one's Zone of Proximal Development (ZPD; Vygotsky, 1978). "Intentional content" is prepared with the aim of enhancing students' deeper understanding of the 
content. "Professional educator" serves as a constant observer providing support, comprehensive feedback, and student assessment. For this reason, we believe that the flipped classroom could be important as a facilitator of a constructivist environment of self-determined or internally motivated learning.

Figure 1 presents a tentative hypothesis of the potential associations of the constructivist learning environment with the FCM through the four pillars of flipped learning.

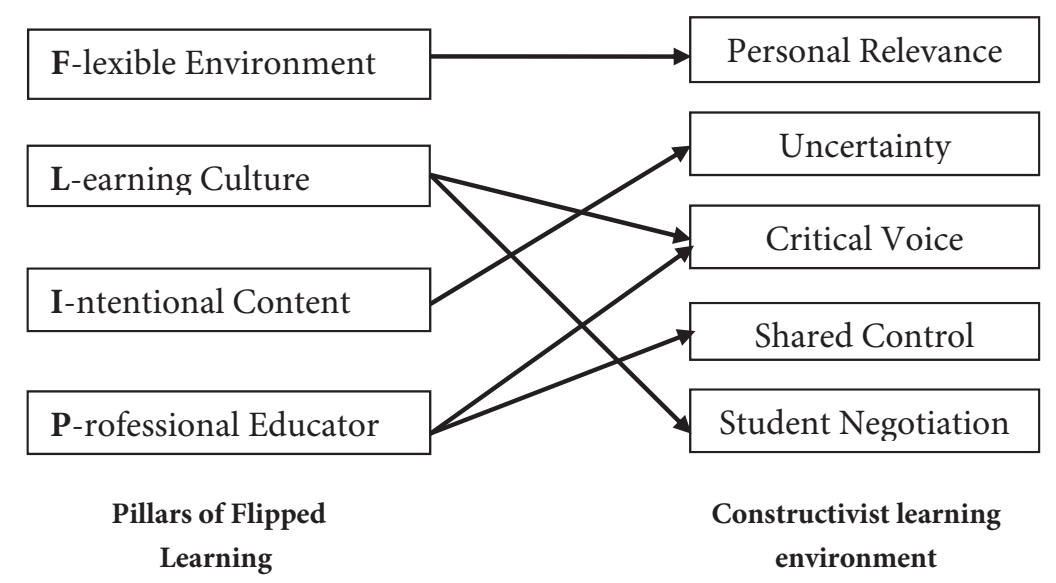

Figure 1. Facilitation of a Constructivist Environment through the Four Pillars of Flipped Learning. Hypothesized manifestations of the four pillars in a constructivist environment.

We are not aware of any empirical studies specifically testing the constructivist-environment dimensions in the flipped classroom, as defined by Taylor et al. (1997), though some studies have been published on the topic (e.g., MacKinnon, 2015; Özüdoğru \& Aksu, 2020; Xu \& Shi, 2018). It would be interesting to investigate further how the learning dynamics, as presented through the four pillars, could be associated with evaluation of the learning environment.

As Figure 1 shows, it could be expected that the flexible environment of the flipped classroom contributes to better evaluation of the personal relevance of studying material. For example, personal experience-based learning was evaluated as more constructivist than traditional lecture-based learning (Alt, 2015). We could, therefore, expect the flipped classroom learning culture to be associated with critical voice and student negotiation, given that it promotes a dynamic learning according to the ZPD (Zone of Proximal Development; Vygotsky, 1978), and both these dimensions are based on social interaction. 
In relation to the second pillar associated with dynamic learning, one study found that a learning potential or gain, defined as an increase in intelligence score after applying an instructional intervention, was not correlated with personality, although personality was correlated with intelligence (Đapo et al., 2012). This finding suggests the importance of dynamic learning in line with ZPD, as such learning could presumably alleviate the potential negative effects of personality or other dispositions on learning. Similarly, it was found that student mathematical potential was developed by teacher scaffolding and applying the constructivist approach in the flipped classroom (Cevikbas \& Kaiser, 2020). The intentional content of flipped learning could also facilitate the acceptance of uncertainty in science or the learning material. Thus, content should be prepared strategically to create an environment that supports critical skills as well as unbalanced situations that question the truth (Tunca, 2015). Finally, the professional educator who is providing constant feedback to students should presumably facilitate the students' critical voice and shared control. Although shared control was negatively correlated with critical thinking, empowering students by encouraging their involvement in assessment decisions and practices may not be a bad strategy. For example, one study showed a high congruence between medical students and family physicians on the logicality and practicality evaluation of the multiple-choice test questions on cardiac and pulmonary pathophysiology (Secic et al., 2017). This finding implies that students should be involved in the qualitative assessment of exam questions, which would be in line with constructive alignment (Biggs, 1996; Biggs \& Tang, 2007, quoted in Secic et al., 2017) or the reconciliation of the intended learning outcomes, teaching and learning activities, and assessment tasks, so that students could adjust their learning to the learning requirements. Giving students more important roles in assessment would also support a student-centred approach (Secic et al., 2017).

Given the above, it would be interesting to explore whether similar relationships could be identified during the pandemic. Although it seems that there are few studies specifically addressing the constructivist environment during the pandemic, we did find a few studies that could shed more light on this topic. As mentioned, flipped learning during the pandemic has apparently shown a decrease in communication or technology support. As one study found, although students had better grades as they progressed through the semesters, they still experienced a decrease in peer negotiations and social support (Zuckerman et al., 2021). Other findings showed difficulties in using self-learning modules, as indicated by unfamiliar words, a lack of supporting resources, and slow internet connections, which imposed additional demands on teachers to create a productive learning environment (Funa \& Talaue, 2021). These findings point to the necessity of further exploring other critical 
aspects of self-regulated learning, such as basic psychological needs, in order to maintain a constructivist environment. The lack of peer interactions and flawed technology may be associated with an unsatisfied need for relatedness and competence, respectively, which we describe in more detail in the next section.

\section{Self-Determined Learning in the Constructivist Pandemic-Induced Flipped Classroom}

As stated, a constructivist flipped learning environment does not always mean that self-determined learning is happening. Numerous studies have been conducted on the benefits of flipped learning, most relating to cognitive learning outcomes, but its relationship with motivation remains unexplored (Sergis et al., 2018). A meta-analysis of 114 studies (van Alten et al., 2019) could not include studies on the effects of the flipped method on motivation since there were so few of them. The same applies to constructivist environment research. As noticed by Loyens and Gijbels (2008, quoted in Alt, 2015), past research focused on the cognitive outcomes of constructivist learning instead of numerous other variables affecting student self-efficacy, including motivation. Later studies stressed the positive contributions of a constructivist learning environment to motivation. For example, CetinDindar (2015) pointed out that motivation should be integrated into constructivist learning if the latter is organized beyond rote memorization. This was supported by her finding of a negative correlation between a constructivist learning environment and motivation to learn science, except when students had an opportunity to relate science to real-world issues (in which case the correlation was positive).

Regarding the importance of motivation, one might be curious how motivation is specifically associated with a constructivist learning environment. Self-determined learning is guided by internal motivation, but not all motivation is internal, and there are fluctuations on the external - internal regulation continuum. Müller and Louw (2004) identified four types of motivation, with an emphasis on education, differing by degree of internalization (Ryan and Deci, 2000): external regulation, introjected regulation, identified regulation, and integrated regulation. External regulation describes learning regulated by external rewards and reinforcements (e.g. grades). Introjected regulation describes behaviour that is manifested but not internally regulated by the person (e.g. the preservation of self-esteem in front of others). Identified regulation is related to valuing the learned material (e.g. students believe that assessment is important). Integrated regulation is related to integrating values into a coherent self. This continuum has been verified in various contexts, including psychotherapy (Alispahić et al., 2013), where extrinsic regulation was negatively, and integrated and identified regulation positively, correlated with intrinsic motivation. 
According to self-determination theory (Deci \& Ryan, 2000), transformation from external regulation to self-determined (intrinsic) motivation depends on the satisfaction of the three basic psychological needs: autonomy, competence, and relatedness. Autonomy is a sense of freely initiating and regulating one's own actions. Competence is a sense of having skills and being effective and competent at an activity. Relatedness is a sense of belonging, shared purpose, and connection with other significant people, and is manifested as a need to be with other people and integrated within social community. Although relatedness seems to be secondary to intrinsic motivation, as people can be engaged in intrinsically motivating activities in solitude, relational support may manifest as a sense of secure base and have a distal effect on intrinsic motivation (Deci \& Ryan, 2000). Self-determined learning can be achieved through the implementation of instructional design that promotes basic needs, as proposed by Müller and Louw (2004): support for autonomy is viable through various options for learners, support for competence is provided through consistent feedback on a learner's progress, and support for relatedness is achieved by creating a cooperative atmosphere. The pedagogical relevance of integrating basic needs into the educational context is reflected in the potential for a student to gradually develop an interest in an activity in which they were initially uninterested. Another argument for this integration would be an almost tangible resemblance among the constructivist dimensions of personal relevance, uncertainty, critical voice, shared control, and student negotiation and basic needs, where these dimensions "apparently cover the needs for motivation to learn" (CetinDindar, 2015, p. 235).

As research has shown, basic psychological needs are associated with numerous learning outcomes, situational interest, and intrinsic motivation. For example, support for autonomy, competence, and relatedness was a good predictor of interest in vocational learning in the progressing stages of the project, with social relatedness being the most influential need in all stages (Minnaert et al., 2011). Another interview-based study found relatedness to be the most salient psychological need, followed by competence and autonomy (Trenshaw et al., 2016). The importance of relatedness was described as the need being promoted through projects, as the need that enables competence building, and as a prerequisite, along with competence, for motivation. Based on these findings, it seems that the presumed importance of autonomy should not be taken for granted. Instead, Trenshaw et al. (2016) proposed the term "structural stability conceptualization," according to which the aggregate contribution of all three needs is necessary to build motivation, but in different students the satisfaction of some needs may be absent, which makes the particular need salient. As recommended by the authors, rather than automatically pursuing autonomy, it would be more appropriate to take a holistic stance towards basic needs. 
Given the pandemic, it would be interesting to observe whether any significant changes took place regarding the salience of individual needs. In an analysis of nine studies published during the pandemic in Asia and the United States that encompassed different influential motivation theories, including self-determination theory, the most relevant topics were motivation, socialization, and self-directedness (Chiu et al., 2021). In the pandemic-related circumstances, it seems that competence plays a prevailing role in university students' well-being. In two cross-cultural, large-scale studies on the student sample from Austria and Finland (Holzer, Lüftenegger, et al., 2021) and on the adolescent sample from eight countries across North America, Asia, and Europe (Holzer, Korlat, et al., 2021), competence was a consistent predictor of positive emotion and learning motivation, while relatedness and autonomy, although correlated with positive emotion, selfregulated learning and intrinsic motivation, seemed to play a secondary role. This coincided with digital competence being the most significant positive predictor of student engagement (X. Wang et al., 2021). Social relatedness may have minor relevance due to the phenomenon of cocooning (Holzer, Lüftenegger, et al., 2021) - taking precautionary measures of self-isolation to stay healthy and safe - which could reflect a contextual interpretation of relatedness. On the other hand, social relatedness was an important predictor of positive emotions in the adolescent sample, pointing to the importance of being socially connected during the pandemic (Holzer, Korlat, et al., 2021). The importance of autonomy may also be reframed to have characteristics other than autonomy support (Holzer, Korlat, et al., 2021). In times of great insecurity and unsafety, having too much autonomy could presumably be associated with a loss of structure. For example, as a therapist style, supportive autonomy was found to predict personality plasticity indirectly through the perception of a therapy benefit (Hadžiahmetović et al., 2016). This finding shows that the perception of contextual usefulness may mediate how autonomy-supportive style contributes to behavioural flexibility. Since the contextual benefits in the pandemic are presumably smaller than under the usual circumstances, autonomy might not facilitate flexibility in these times or thus be as important.

As for the seemingly minor relevance of relatedness, studies point to an assumption that it may come to the fore through the satisfaction of other learning-relevant needs, especially competence, through dynamic online supportive systems. For example, two pre-pandemic studies showed that the flipped classroom was positively evaluated with respect to peer interactions (van der Velde et al., 2020; Zainuddin \& Perera, 2017), autonomous learning skills, intrinsic motivation, and online competence with the assignments (Zainuddin \& Perera, 2017). First-year students, however, though appreciating relatedness and pre-class preparation in flipped learning, also needed explicit guidance and expectations from the instructor, as well as 
occasional external incentives (van der Velde et al., 2017). It seems that, for less experienced learners, more straightforward instructions are required to give them a sense of competence. Taking into consideration that many students have experienced flipping for the first time during the pandemic, this may well apply to them. In line with this, a study conducted under the pandemic conditions (Zhou et al., 2021) showed that relatedness was not directly associated with perceived learning gain and satisfaction but indirectly mediated by online self-regulated learning. This finding indicates that the closer students felt to their teachers and peers, the more they engaged in self-regulated learning by goal-setting, task strategies, self-evaluation, environment structuring, help-seeking, and time management, which in turn enhanced their perception of learning gains and satisfaction. The effects of competence and autonomy on positive emotion, moderated by self-regulated learning, were partially confirmed in other study (Holzer, Lüftenegger, et al., 2021). Thus, while relatedness may not seem as salient during the pandemic as other needs, support for relatedness may be an initial step in taking control over learning. The learning environment, however, may also play a very important role. For example, experimentally instructed digital support for the three basic needs enhanced students' sense of autonomy, relatedness, and competence, which subsequently predicted the student learning engagement (Chiu, 2021). Considering the importance of the learning environment to the satisfaction of basic needs, we attempted to examine these relations closely within a common conceptual framework.

\section{A common framework}

We have elaborated previously on the importance of integrating autonomy, competence, and relatedness support into the constructivist approach, as well as pointed out the importance of the flipped classroom as a conduit of the constructivist environment. Thus, following this rationale, our further steps would be to integrate all three concepts into a common framework. This framework is presented in Figure 2. It is important to note that the intended framework is only a conceptual outline or a scheme rather than a theorydriven model, leaving space for accommodation based on future findings. Another important point is that this framework should probably be applicable to pre- or post-pandemic education, but the middle term - the usefulness of the flipped classroom - could carry more weight during the pandemic.

According to the common framework, a constructivist environment is presumed to facilitate the support of the basic needs of autonomy, competence, and relatedness, which in turn could positively affect learning outcomes but only if the pandemic-induced flipped classroom is perceived as useful. As a "venue" where constructivist learning takes place, the organization and 
conduction of the flipped classroom during the pandemic has been placed under the great pressure of responsibility. The flipped classroom might not necessarily be effective, in which case the perceptions of the method by students, as active protagonists of learning, becomes crucial, since further use of the method depends on the students' perceptions of its success (ColomoMagaña et al., 2020).

For this reason, we believe that the perception of the usefulness of the FCM may moderate the constructivist facilitation of basic needs. Considering this, we propose the three usefulness dimensions of communicative, instrumental, and pedagogical function of the flipped classroom (Colomo-Magaña et al., 2020) because the usefulness of alternative online learning methods during the pandemic may be of central importance.

Another important reason for specifically proposing these three dimensions rather than other ways of measuring the flipped classroom's efficacy is that these dimensions are presumably most closely associated with the basic needs of autonomy, competence, and relatedness, as presented in Figure 2. As described by Colomo-Magaña et al. (2020), the communicative dimension assesses information presentation - the way a message is conveyed and social interactions in the class - and the improvement of communicative competence. The instrumental dimension involves the assessment of operational classroom functions, problems and situations originating from technological resources, and the development of cognitive skills or cognitive competence. The pedagogical dimension focuses on the assessment of learning and teaching processes, the acquisition and regulation of learning, and types of learning and feedback. As such, we presume that this dimension is most closely related to autonomy and self-regulated learning.

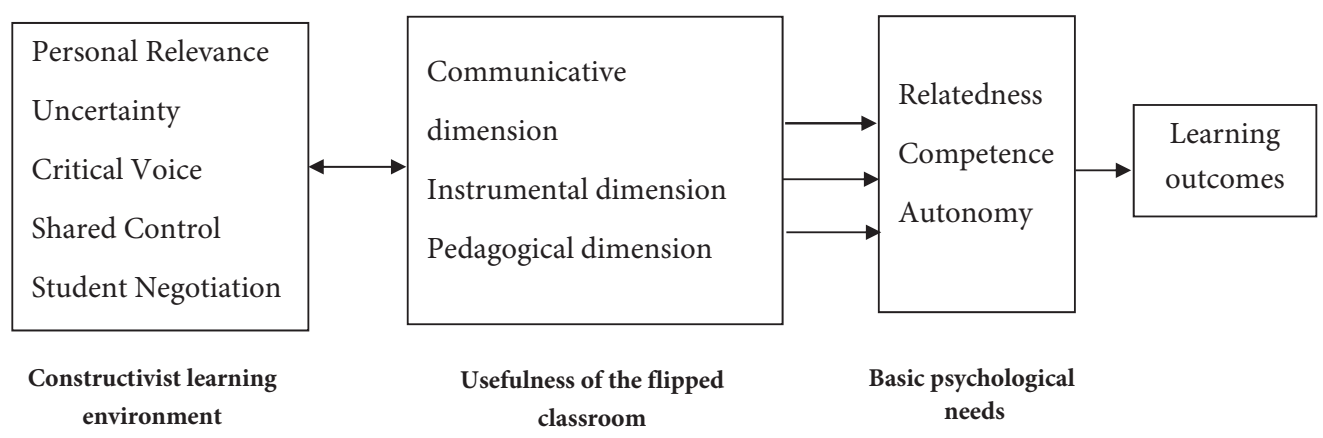

Figure 2. A Common Framework. A proposed scheme of the relationships among the constructivist environment, flipped classroom, and basic psychological needs. 
As proposed in Figure 2, it would be worth further investigating whether the greater perceived usefulness of flipped learning leads to a more positive perception of personal relevance, uncertainty, critical voice, shared control, or student negotiation, as well as whether the perception of usefulness enhances a sense of autonomy, competence, and relatedness, in which case one positive effect of the constructivist environment on basic psychological needs would be expected in those flipped classrooms that are perceived as having a positive influence on communicative, cognitive, and self-regulated competence. It is also important to underline the hypothesized recursive relationship between the constructivist environment and the flipped classroom, as the usefulnessmediated relationship between the constructivist environment and basic needs could be equally conceivable. In that case, the positive evaluation of a constructivist environment would increase the perception of its usefulness, which in turn would also increase the support for the basic needs of autonomy, competence, and relatedness - and hence learning outcomes. In other words, either proposition is inclined to take the usefulness of flipping into consideration, which could help in strategically planning for the support of basic needs. The relationship between the constructivist environment and the usefulness of the flipped method would also reflect the hypothesized relationship between the four pillars of flipped learning and the constructivist environment. The proposed relationship should be interpreted cautiously and more as an orientation than a well-rounded model until novel pandemicrelated findings can shed more light on hypothesized relations.

\section{Questions Raised}

Rather than referring to this section as a "discussion," because the discussion is far from over, or a "conclusion," as we have more questions now than at the outset of this endeavour, we refer to the remaining issues as "questions raised". In this review paper, we made efforts to synthesize three broad constructs in a common conceptual framework under the extraordinary conditions of the COVID-19 pandemic. The integration of the flipped classroom method, the constructivist learning approach, and basic SDT needs proved an interesting and explorative, although arduous, endeavour. While we probably pointed out potential new directions in future research, new questions have been raised in the process. Some predecessors of this topic (e.g. Chiu et al., 2021, pp. 3-4) have already summarized the major challenges in future developments: maintaining student and teacher motivation in the transition from face-toface to online learning, preparing students for future learning, addressing the psychological needs of students through online learning, promoting a technology-supported, peer-collaborative environment, enhancing instructors' efficacy at applying motivational theories in practice, supporting 
instructors' well-being, addressing equity in technology-mediated learning, and re-examining policy responses to fight the COVID-19 pandemic through cross-cultural comparisons. The outlined challenges could be used as practical directions for proceeding further in the implementation of new instructional designs in the new normal. In addition, we would extend the list of main concerns by pointing out the domains that emerged as important theoretical and empirical challenges in this review process:

- A variety of conceptualizations and a variety of research practices: on the one hand, it is very encouraging to have open access to all pandemic-related scientific reports from which to plan further studies. On the other hand, there is little space for the comparability of the findings, given the variety of methods (e.g. the flipped classroom, online learning, or online-supported collaborative learning). This calls for more meta-analytic or cross-cultural research applying the same methodology to generalize the findings beyond the respective universities.

- In this respect, the effects of the FCM seem to be more extensively studied in higher education, while the constructivist environment studies seem to be more prevalent in secondary education. Thus, testing a proposed framework with regard to age groups might be a useful practice prior to potential implementations.

- Quickly updating pandemic-related publication record: while it is a good practice and necessary to have a great amount of research on education during the pandemic, it remains too early to draw general conclusions about what works, which makes any synthesis harder.

- Transference between pre-pandemic and pandemic research findings (except for longitudinal studies initiated prior to the pandemic): sometimes it seems difficult to capture the consistency and change adequately, which makes it harder to register the changes specifically caused by the pandemic (e.g. whether the increased need for relatedness is caused by the flipped method per se, the pandemic, or their combination).

- The remains of pre-pandemic issues: for instance, what did not work in the flipped classroom (e.g. technical equipment) prior to the pandemic continues to be a problem during the pandemic.

As for the questions we raised in the beginning, we could summarize the synthesis provided in the following as:

- The pros and cons of the flipped classroom should be considered interdependently; on the one side, the FCM enables constructivist learning. In unprecedented times, such as the pandemic, applying the FCM could provide a flexible venue for students and teachers to construct their own meaning of learning materials and give more personal relevance 
to it possibly as never before. On the other hand, as flexible as this venture may seem, additional education on how to apply the FCM for those with a lack of prior experience may be critical in its implementation. More specifically, it would be necessary to provide technical support and educate on how to adapt syllabi to the new circumstances.

- Constructivist learning is possible, as long as the tenets of flipped learning are respected; the flipped learning principles, including flexible environment, learning culture, intentional content, and professional educator, should be applied especially during the pandemic to better facilitate constructivist learning. Flexible environment could be implemented as a combination of online and live lectures/tasks. Learning culture could be implemented through different teaching approaches which could meet the individual student's needs. Intentional content could be adjusted in a way that the challenges posed by the pandemic could be integrated in learning materials. The principle of professional educator should consider flexible communication between teachers and students, as well as implementing creative learning tasks with more frequent feedback on task accomplishments.

- Constructivist environment can be created in the pandemic-constructed flipped classroom, but communication, technology, and digital competence seem especially important for the flipped classroom constructivist approach - as shown in research, a lack of knowledge about digital platforms on the part of teachers or students seems to be the main obstacle in effectively maintaining constructivist environment.

- The flipped classroom and constructivist approach may facilitate basic needs, but it is important that the environment is evaluated as useful with regard to each need specifically; as proposed in a common framework, communicative dimension of the usefulness of the flipped classroom may be related to need for relatedness, instrumental dimension may be related to need for competence, and pedagogical dimension may be related to need for autonomy, but these hypothetical relations should be empirically explored in the future, and

- Competence seems to be more important during the pandemic, but relatedness may indirectly be related to learning outcomes - as research has shown, satisfying need for competence may be an important prerequisite for satisfying need for relatedness as well, but more research on this topic would also be needed to verify these assumptions.

While the list of theoretical, empirical, and practical implications is far from exhaustive, we hope to have offered an initial synthesis as a starting point for further investigation of the common framework during the pandemic. 


\section{References:}

Abeysekera, L., \& Dawson, P. (2015). Motivation and cognitive load in the flipped classroom: Definition, rationale and a call for research. Higher Education Research and Development, 34(1), 1-14. doi:10.1080/07294360.2014.934336.

Ahmad, C. N., Ching, W. C., Yahaya, A., \& Abdullah, M. F. (2015). Relationship between constructivist learning environments and educational facility in science classrooms. Procedia- - Social and Behavioral Sciences, 191, 1952-1957. doi: 10.1016/j.sbspro.2015.04.672.

Alispahić, S., Tuce, Đ., Hasanbegović-Anić, E., \& Hadžiahmetović, N. (2013, March): Motivacija klijenata za psihoterapiju na kontinuumu samoodređenja. [Client motivation for therapy on self-determination continuum]. Paper presented at the Third congress of psychologists of Bosnia and Herzegovina, Mostar.

Alt, D. (2015). Assessing the contribution of a constructivist learning environment to academic self-efficacy in higher education. Learning Environments Research, 18(1), 47-67. doi:10.1007/s10984-015-9174-5.

Beason-Abmayr, B., Caprette, D. R., \& Gopalan, C. (2021). Flipped teaching eased the transition from face-to-face teaching to online instruction during the COVID-19 pandemic. Advances in Physiology Education, 45(2), 384-389. doi: 10.1152/advan.00248.2020.

Birgili, B., Seggie, F. N., \& Oğuz, E. (2021). The trends and outcomes of flipped learning research between 2012 And 2018: A descriptive content analysis. Journal of Computers in Education. doi:10.1007/s40692-021-00183-y.

Cetin-Dindar, A. (2015). Student motivation in constructivist learning environment. EURASIA Journal of Mathematics, Science and Technology Education, 12(2). doi:10.12973/eurasia.2016.1399a.

Cevikbas, M., \& Kaiser, G. (2020). Flipped classroom as a reform-oriented approach to teaching mathematics. ZDM, 52(7), 1291-1305. doi:10.1007/s11858-020-01191-5.

Chiu, T. K. (2021). Applying the self-determination theory (SDT) to explain student engagement in online learning during the COVID-19 pandemic. Journal of Research on Technology in Education, 1-17. doi: 10.1080/15391523.2021.1891998.

Chiu, T. K., Lin, T., \& Lonka, K. (2021). Motivating online learning: The challenges of COVID-19 and beyond. The Asia-Pacific Education Researcher, 30(3), 187-190. doi:10.1007/s40299-021-00566-w.

Chriscaden, K. (2020). Impact of COVID-19 on people's livelihoods, their health and our food systems. Retrieved from https://www.who.int/news/item/13-10-2020impact-of-covid-19-on-people's-livelihoods-their-health-and-our-food-systems.

Christian, D. D., McCarty, D. L., \& Brown, C. L. (2020). Experiential education during the COVID-19 pandemic: A reflective process. Journal of Constructivist Psychology, 1-14. doi:10.1080/10720537.2020.1813666.

Collado-Valero, J., Rodríguez-Infante, G., Romero-González, M., Gamboa-Ternero, S., Navarro-Soria, I., \& Lavigne-Cerván, R. (2021). Flipped classroom: Active methodology for sustainable learning in higher education during social distancing due to COVID-19. Sustainability, 13(10), 5336. doi:10.3390/su13105336.

Colomo-Magaña, E., Soto-Varela, R., Ruiz-Palmero, J., \& Gómez-García, M. (2020). University students' perception of the usefulness of the Fflipped Classroom Methodology. Education Sciences, 10(10), 275. doi:10.3390/educsci10100275. 
Deci, E. L., \& Ryan, R. M. (2000). The "what" and "why" of Goal Pursuits: Human needs and the self-determination of behavior. Psychological Inquiry, 11(4), 227268. doi:10.1207/s15327965pli1104_01.

Di Pietro, G., Biagi, F., Costa, P., Karpiński Z., \& Mazza, J, The likely impact of COVID-19 on education: Reflections based on the existing literature and international datasets, EUR 30275 EN, Publications Office of the European Union, Luxembourg, 2020, ISBN 978-92-76-19937-3, doi:10.2760/126686, JRC121071.

Dziuban, C., Graham, C. R., Moskal, P. D., \& Sicilia, N. (2018). Blended learning: the new normal and emerging technologies. International Journal of Educational Technology in Higher Education, 15(3), 1-16. doi: 10.1186/s41239-017-0087-5.

Đapo, N., Kolenović-Đapo, J., Hadžiahmetović, N., \& Fako, I. (2012). The relationship of Eysenck's Giant Three with fluid and crystallized intelligence and learning potential among adolescents. Temas em Psicologia, 20(1), 71-85.

Flipped Learning Network (FLN). (2014) The Four Pillars of F-L-I-P ${ }^{\mathrm{Tm}}$ Retrieved from http://www.flippedlearning.org/definition.

Fulgosi, A. (1997). Psihologija ličnosti - Teorija i istraživanja. [Personality psychology - theory and research]. Zagreb: Školska knjiga.

Funa, A. A., \& Talaue, F. T. (2021). Constructivist learning amid the COVID-19 pandemic: Investigating students' perceptions of biology self-learning modules. International Journal of Learning, Teaching and Educational Research, 20(3), 250264. doi:10.26803/ijlter.20.3.15.

Hadžiahmetović, N., Alispahić, S., Tuce, Đ., \& Hasanbegović-Anić, E. (2016). Therapist's interpersonal style and therapy benefit as the determinants of personality self-reports in clients. Vojnosanitetski Pregled, 73(2), 135-145. doi: 10.2298/vsp140911141h.

Hew, K. F., Jia, C., Gonda, D. E., \& Bai, S. (2020). Transitioning to the "new normal" of learning in unpredictable times: Pedagogical practices and learning performance in fully online flipped classrooms. International Journal of Educational Technology in Higher Education, 17(1). doi:10.1186/s41239-020-00234-x.

Holzer, J., Korlat, S., Haider, C., Mayerhofer, M., Pelikan, E., Schober, B., . . . Lüftenegger, M. (2021). Adolescent well-being and learning in times of COVID19-A Multi-country study of basic psychological need satisfaction, learning behavior, and the mediating roles of positive emotion and intrinsic motivation. PLOS ONE, 16(5). doi:10.1371/journal.pone.0251352.

Holzer, J., Lüftenegger, M., Korlat, S., Pelikan, E., Salmela-Aro, K., Spiel, C., \& Schober, B. (2021). Higher education in times of Covid-19: University Students' basic Need Satisfaction, Self-regulated learning, and well-being. AERA Open, 7, 233285842110031. doi:10.1177/23328584211003164.

Hrastinski, S. (2019). What Do We Mean by Blended Learning? TechTrends, 63(5), 564-569. doi:10.1007/s11528-019-00375-5.

Jain, S., Lall, M., \& Singh, A. (2020). Teachers' Voices on the Impact of COVID-19 on School Education: Are Ed-Tech Companies Really the Panacea? Contemporary Education Dialogue, 18(1), 58-89. doi:10.1177/0973184920976433.

Kelly, G. A. (1955). The psychology of personal constructs. New York: Norton.

Kwan, Y. W., \& Wong, A. F. (2014). The constructivist classroom learning environment and its associations with critical thinking ability of secondary school students in 
Liberal Studies. Learning Environments Research, 17(2), 191-207. doi:10.1007/ s10984-014-9158-x.

Latorre-Cosculluela, C., Suárez, C., Quiroga, S., Sobradiel-Sierra, N., Lozano-Blasco, R., \& Rodríguez-Martínez, A. (2021). Flipped classroom model before and during Covid-19: Using technology to develop 21st century skills. Interactive Technology and Smart Education, Ahead-of-print(Ahead-of-print). doi:10.1108/itse-08-2020-0137.

MacKinnon, G. (2015). Determining useful tools for the flipped science education classroom. Contemporary Issues in Technology and Teacher Education, 15(1), 44-55.

McLeod, S. A. (2019). Constructivism as a theory for teaching and learning. Retrieved from https://www.simplypsychology.org/constructivism.html.

Minnaert, A., Boekaerts, M., de Brabander, C., \& Opdenakker, M. (2011). Students' experiences of autonomy, competence, social relatedness and interest within a CSCL environment in vocational education: The case of commerce and Business Administration. Vocations and Learning, 4(3), 175-190. doi:10.1007/s12186-011-9056-7.

Müller, F. H., \& Louw, J. (2004). Learning environment, motivation and interest: Perspectives on self-determination theory. South African Journal of Psychology, 34(2), 169-190. doi:10.1177/008124630403400201.

Nix, R. K., Fraser, B. J., \& Ledbetter, C. E. (2005). Evaluating an integrated science learning environment using the constructivist learning environment survey. Learning Environments Research, 8(2), 109-133. doi:10.1007/s10984-005-7251-x.

Norberg, A., Dziuban, C. D., \& Moskal, P. D. (2011). A time-based blended learning model. On the Horizon, 19(3), 207-216, doi: 10.1108/10748121111163913.

Ongowo, R. O., Indoshi, F., C., \& Ayere. M. A. (2014). Relationship between Students' Perception of a Constructivist Learning Environment and Motivation towards Biology in Siaya County, Kenya. Global Journal of Interdisciplinary Social Sciences, 3(4), 23-30.

Özüdoğru, M., \& Aksu, M. (2019). Pre-service teachers' achievement and perceptions of the classroom environment in flipped learning and traditional instruction classes. Australasian Journal of Educational Technology, 27-43. doi:10.14742/ajet.5115.

Piaget, J. (1954). The construction of reality in the child. New York: Basic Books.

Ryan, R. M., \& Deci, E. L. (2000). Self-determination theory and the facilitation of intrinsic motivation, social development, and well-being. American Psychologist, 55(1), 68-78. doi:10.1037/0003-066x.55.1.68.

Secic, D., Husremovic, D., Kapur, E., Jatic, Z., Hadziahmetovic, N., Vojnikovic, B., . . . Hadzic, A. (2017). Medical students' vs. family physicians' assessment of practical and logical values of pathophysiology multiple-choice questions. Advances in Physiology Education, 41(1), 62-68. doi:10.1152/advan.00145.2015.

Sergis, S., Sampson, D. G., \& Pelliccione, L. (2018). Investigating the impact of flipped classroom on students' learning experiences: A Self-Determination theory approach. Computers in Human Behavior, 78, 368-378. doi: 10.1016/j.chb.2017.08.011.

Shih, W., \& Tsai, C. (2017). Students' perception of a flipped classroom approach to facilitating online project-based learning in marketing research courses. Australasian Journal of Educational Technology. doi:10.14742/ajet.2884.

Tadesse, S., \& Muluye, W. (2020). The Impact of COVID-19 Pandemic on Education System in Developing Countries: A Review. Open Journal of Social Sciences, 08(10), 159-170. doi:10.4236/jss.2020.810011. 
Talley, C. P., \& Scherer. S (2013). The enhanced Flipped Classroom: Increasing academic performance with Student-recorded lectures and practice testing in A "Flipped" STEM course. The Journal of Negro Education, 82(3), 339. doi:10.7709/ jnegroeducation.82.3.0339.

Tang, T., Abuhmaid, A. M., Olaimat, M., Oudat, D. M., Aldhaeebi, M., \& Bamanger, E. (2020). Efficiency of flipped classroom with online-based teaching under COVID-19. Interactive Learning Environments, 1-12. doi:10.1080/10494820.2020.1817761.

Taylor, P. C., Fraser, B. J., \& Fisher, D. L. (1997). Monitoring constructivist classroom learning environments. International Journal of Educational Research, 27(4), 293 302. doi:10.1016/s0883-0355(97)90011-2.

Torres Martín, C., Acal, C., El Homrani, M., \& Mingorance Estrada, Á. (2021). Impact on the virtual learning environment due to COVID-19. Sustainability, 13(2), 582. doi:10.3390/su13020582.

Trenshaw, K. F., Revelo, R. A., Earl, K. A., \& Herman, G. L. (2016). Using Self Determination Theory Principles to Promote Engineering Students' Intrinsic Motivation to Learn. International Journal of Engineering Education, 32, 3(A), 1194-1207.

Tunca, N. (2015). The regression level of constructivist learning environment characteristics on classroom environment characteristics supporting critical thinking. Eurasian Journal of Educational Research, 60, 181-200. doi:10.14689/ejer.2015.60.11.

van Alten, D. C., Phielix, C., Janssen, J., \& Kester, L. (2019). Effects of flipping the classroom on learning outcomes and satisfaction: A meta-analysis. Educational Research Review, 28, 100281. doi:10.1016/j.edurev.2019.05.003.

van der Velde, R., Blignaut - van Westrhenen, N., Labrie, N. H., \& Zweekhorst, M. B. (2020). 'The idea is nice... but not for me': First-year students' readiness for large-scale 'flipped lectures' - what (de)motivates them? Higher Education, 81(6), 1157-1175. doi:10.1007/s10734-020-00604-4.

von Glasersfeld, E. V. (1974). Piaget and the radical constructivist epistemology. In: C. D. Smock \& E. von Glasersfeld (Eds.) Epistemology and education. (pp. 1-12). Athens GA: Follow Through Publications.

Vygotsky, L. (1978). Mind in Society: The Development of Higher Psychological Processes. Cambridge, MA: Harvard University Press.

Wang, X., Zhang, R., Wang, Z., \& Li, T. (2021). How does Digital Competence reserve university students' psychological well-being during the pandemic? An investigation from self-determined theory. Frontiers in Psychology, 12. doi:10.3389/ fpsyg.2021.652594.

$\mathrm{Xu}, \mathrm{Z}$., \& Shi, Y. (2018). Application of constructivist theory in flipped classroom - take college English teaching as a case study. Theory and Practice in Language Studies, 8(7), 880. doi:10.17507/tpls.0807.21.

Zainuddin, Z., \& Perera, C. J. (2017). Exploring students' competence, autonomy and relatedness in the flipped classroom pedagogical model. Journal of Further and Higher Education, 1-12. doi:10.1080/0309877x.2017.1356916.

Zhou, X., Chai, C. S., Jong, M. S., \& Xiong, X. B. (2021). Does relatedness matter for online self-regulated learning to promote perceived learning gains and satisfaction? The Asia-Pacific Education Researcher, 30(3), 205-215. doi:10.1007/ s40299-021-00579-5. 
Zuckerman, A. L., Hardesty, R. A., Denaro, K., Lo, S. M., \& Owens, M. T. (2021). Effects of remote teaching in a crisis on equity gaps and the Constructivist learning environment in an introductory biology course series. Journal of Microbiology \& Biology Education, 22(1), 1-11. doi:10.1128/jmbe.v22i1.2293.

\title{
Prednosti i nedostaci obrnute učionice: Konstruktivističko i samoodređeno učenje za vreme pandemije COVID-19
}

\author{
Nina Hadžiahmetović* \\ Odsjek za psihologiju, Filozofski fakultet, Univerzitet u Sarajevu
}

\begin{abstract}
Metoda obrnute učionice (MOU) je zasnovana na samostalnom onlajn učenju koje je praćeno naknadnim interakcijama učenika sa nastavnikom i pokazala je određene prednosti u odnosu na tradicionalno učenje, čak i u predpandemijskom kontekstu. MOU može da posluži i za primenu konstruktivističkog pristupa učenju koje karakteriše aktivna konstrukcija znanja umesto pasivne konzumacije unapred određenih koncepata. Oba pristupa bi trebalo da omoguće zadovoljenje osnovnih psiholoških potreba autonomije, kompetencije i povezanosti, kako pretpostavlja teorija samoodređenja (TSO). Međutim, nakon izbijanja pandemije COVID-19, metoda obrnute učionice je nametnuta mnogim univerzitetima uz manjak resursa za primenu konstruktivističkog pristupa i zadovoljenje osnovnih psiholoških potreba studenata. Uzimajući u obzir izazove obrnutog poučavanja indukovanog pandemijom, ovaj pregledni rad ima za cilj da se usmeri na sledeće probleme uz korišćenje integrativnog teorijskog okvira: Šta su prednosti i nedostaci obrnute učionice indukovane pandemijom?; Da li je konstruktivističko učenje omogućeno tokom pandemije i u kojoj meri?; Na koji način je moguće kreirati konstruktivističko okruženje u obrnutoj učionici nastaloj kao rezultat pandemije?; Može li obrnuta učionica biti korišćena kao virtuelni medijator između konstruktivističkog okruženja i osnovnih psiholoških potreba? U radu je dalje prikazan konceptualni okvir o povezanosti konstruktivističkog okruženja i osnovnih psiholoških potreba preko percipirane korisnosti obrnute učionice posredovane tehnologijom. Konkretno, u radu se dalje istražuje da li komunikativna, instrumentalna i pedagoška funkcija obrnute učionice može da doprinese zadovoljenju osnovnih psiholoških potreba studenata. Na kraju se razmatraju izazovi praktične i empirijske primene teorijskog okvira.
\end{abstract}

Ključne reči: konstruktivističko učenje, obrnuta učionica, osnovne psihološke potrebe, pandemija

* ninochkaha@gmail.com 